\title{
Evaluation of Wheat (Triticum aestivum L.) under Inorganic and Organic Fertilization Using FTIR Spectroscopy
}

\author{
Rashpinder Singh ${ }^{1}$, Manish Bakshi ${ }^{2 *}$, Kuljeet Singh ${ }^{1}$, \\ Sarwan Singh ${ }^{1}$ and Terwinder Singh Brar ${ }^{1}$
}

${ }^{1}$ Department of Agronomy, Lovely Professional University, Punjab, India

${ }^{2}$ School of Agriculture, Lovely Professional University, Punjab, India

*Corresponding author

\begin{tabular}{|l|}
\hline Ke y w o r d s \\
Wheat, INM, \\
Vermicompost, \\
Yield, FTIR \\
\hline Article Info \\
\hline $\begin{array}{l}\text { Accepted: } \\
\text { 04 June } 2019 \\
\text { Available Online: } \\
\text { 10 July 2019 }\end{array}$ \\
\hline
\end{tabular}

\section{Introduction}

Wheat (Triticum aestivum L.) is a predominant winter (rabi) crop of northwestern plain zone and central zone of India. It is the most important food crop in India (after rice) and occupies an area of 302.27 lakh hectares with a total production of 93.50 million tonnes (Anonymous, 2016).
Studies were conducted to evaluate the effect of inorganic and organic fertilization on growth, yield of wheat and nutrient status of the soil. Significant differences in the vegetative growth parameters viz. plant height, number of green leaves, number of tillers/meter row length and yield parameters viz. Spike length, number of spikelets per spike, number of grains/ear, number of ear heads $/ \mathrm{m}^{2}$, test weight, straw yield and biological yield was highest under the application of $50 \%$ recommended dose of fertilizers along with application of $5 \mathrm{t} /$ ha vermicompost $\left(\mathrm{T}_{7}\right)$. Maximum seed yield per meter square $\left(0.630 \mathrm{gm} / \mathrm{m}^{2}\right)$, grain yield $(62.80 \mathrm{q} / \mathrm{ha})$ was recorded with the application of RDF@75\% $+2.5 \mathrm{t} / \mathrm{ha}$ vermicompost $\left(\mathrm{T}_{6}\right)$. Maximum harvest index (66.76) was recorded with the application of RDF@125\% $\left(\mathrm{T}_{4}\right)$. FTIR analysis of the wheat grains revealed maximum area under peaks for amines under the treatment $\mathrm{T}_{5}$. Soil properties were evaluated and maximum available nitrogen $(222.63 \mathrm{~kg} / \mathrm{ha})$, available potassium $(228.01 \mathrm{~kg} / \mathrm{ha})$ and organic carbon $(0.79 \mathrm{~kg} / \mathrm{ha})$ was recorded under treatment $\mathrm{T}_{6}(\mathrm{RDF} @ 75 \%+2.5 \mathrm{t} / \mathrm{ha}$ vermicompost). Maximum available phosphorus $(22.17 \mathrm{~kg} / \mathrm{ha})$ was recorded under the treatment $\mathrm{T}_{7}$ (application of RDF @ $50 \%+5 \mathrm{t} /$ ha vermicompost). Application of $50 \%$ recommended doze of nitrogen along with application of vermicompost @ 5 t/ha gave the highest growth and yield response in wheat. However, soil parameters were at par in all the treatments involving integration of nutrients. Maximum benefit cost ratio was obtained by using recommended doze of fertilizers. 
nutrient availability in organic fertilizers, total dependence on organic fertilizers to fulfill the crop nutrient demands is not possible. Integrated nutrient supply is the systematic approach to nutrient management as the combined application of organic and inorganic sources of nutrients improves the soil fertility and crop productivity (Shree et al., 2014). Organic carbon is the main building block of soil fertility and combined application of organic and inorganic fertilizers increases higher soil organic content (Nkonya et al., 2005, Marin et al., 2007). In this context, it is imperative to adopt those agriculture technologies and methodologies which can improve the production of crop without deteriorating soil health.

\section{Materials and Methods}

The present investigation was carried out at the Departmental farms of Lovely Professional University, Punjab during the rabi season 2017-18 to evaluate the effect of organic and inorganic fertilization on growth and quality of wheat. The soil experimental field was sandy loam in texture, well fertile, acidic in reaction with good drainage. The experiment was divided in to seven treatments replicated thrice and laid out in a Randomized Block design. Wheat variety HD3086 was used at a recommended seed rate of 98.8 $\mathrm{kg} / \mathrm{ha}$. Treatments comprised of $\mathrm{T}_{1}$ : Control, $\mathrm{T}_{2}$ : RDF, $\mathrm{T}_{3}: \mathrm{RDF}+2.5 \mathrm{t} /$ ha vermicompost, $\mathrm{T}_{4}$ : RDF@125\%, T : RDF @ 125\% + 2.5 t/ha vermicompost, $\mathrm{T}_{6}$ : RDF @ 75\% + 2.5 t/ha vermicompost and $\mathrm{T}_{7}$ : RDF @ 50\% + $5 \mathrm{t} / \mathrm{ha}$ vermicompost. Seed rate, fertilizer doze and cultural practices followed were as per the recommended package of practices for wheat (Anonymous, 2013). Thoroughly prepared vermicompost was used and the total requirement of the crop was calculated on nutrient equivalent basis. Observations were recorded on growth and yield parameters using standard methods. Soil samples from each treatment were analyzed for soil nutrient analysis. Organic carbon was estimated using Walkley and Black's Method (Piper, 1966). Available nitrogen was estimated using Alkaline Potassium Permanganate Method (Subbiah and Asija, 1956). Available phosphorus was estimated by Olsen's Method (Olsen et al., 1954) and available potassium was estimated by Flame Photometer (Mervin and Peech, 1951).

\section{FTIR spectroscopic analysis}

Fourier Transform Infra-red Spectroscopy (FTIR) was performed to evaluate the effect of different integrated nutrient management treatments on quality of wheat. Flour of wheat from each treatment was collected. These flour samples were converted into pellets and pellets were cut into thin sections. These thin sections were oven dried and their spectra were recorded on FTIR Spectroscope (SHIMADZU).

\section{Statistical analysis}

The data generated during the course of study was subjected to analysis of variance (ANOVA) and Duncan's multiple-ranged test was performed using SPSS v. 16 software to identify the homogeneous type of the data sets among different treatments for different plant parameters.

\section{Results and Discussion}

Vegetative parameters of wheat crop are presented under Table 1. Maximum plant height $(58.07 \mathrm{~cm})$, number of green leaves (4.87) and number of tillers/meter row length (82.20) was recorded with the application of RDF@ @ 50\% + 5 t/ha Vermicompost $\left(\mathrm{T}_{7}\right)$. Wheat plants recorded maximum length of spike $(13.73 \mathrm{~cm})$, number of spikelets per spike (11.67) and maximum number of grains/ear (29.33) was recorded with the 
application of RDF @ 50\% + 5 t/ha vermicompost $\left(\mathrm{T}_{7}\right)$. Maximum number of ear heads $/ \mathrm{m}^{2}$ (325.67) was recorded with the application of RDF@ @ 125\% ( $\left.\mathrm{T}_{4}\right)$ whereas minimum number of ear heads $/ \mathrm{m}^{2}$ (215.67) was recorded under control (Table 2). Maximum test weight $(45.97 \mathrm{~g})$ of wheat crop in rabi season under different nutrient management treatments was recorded with the application of RDF @ 50\% + 5 t/ha vermicompost $\left(\mathrm{T}_{7}\right)$. Maximum seed yield per meter square $\left(0.630 \mathrm{gm} / \mathrm{m}^{2}\right)$ and maximum grain yield $(62.80 \mathrm{q} / \mathrm{ha})$ was recorded with the application of RDF @ $75 \%+2.5$ t/ha vermicompost $\left(\mathrm{T}_{6}\right)$ whereas minimum seed yield per meter square was recorded under treatment $\mathrm{T}_{1}$ (Table 3). Straw yield (45.80 $\mathrm{q} / \mathrm{ha}$ ) and biological yield (105.44 q/ha) was obtained maximum under the application of 50 $\%$ recommended dose of fertilizers along with application of $5 \mathrm{t} / \mathrm{ha}$ vermicompost $\left(\mathrm{T}_{7}\right)$. Maximum harvest index (66.76) was recorded with the application of RDF @ 125\% ( $\left.\mathrm{T}_{4}\right)$.

Table 4 reveals that there was no significant effect on soil $\mathrm{pH}$ when compared to the initial $\mathrm{pH}$ values. Soil electrical conductivity was recorded maximum $\left(0.17 \mathrm{dSm}^{-1}\right)$ in treatment $\mathrm{T}_{4}$ (application of RDF @ 125\%). Maximum available nitrogen $(222.63 \mathrm{~kg} / \mathrm{ha})$, available organic carbon $(0.79 \mathrm{~kg} / \mathrm{ha})$ and available potassium $(228.01 \mathrm{~kg} / \mathrm{ha})$ was recorded under treatment $\mathrm{T}_{6}$ (RDF @ $75 \%+2.5 \mathrm{t} / \mathrm{ha}$ vermicompost). Maximum available phosphorus $(22.17 \mathrm{~kg} / \mathrm{ha})$ was recorded under the treatment $\mathrm{T}_{7}$ (application of RDF @ 50\% $+5 \mathrm{t} /$ ha vermicompost).

Fourier transform Infra-red spectroscopy (FTIR) was performed for evaluation of quality components in wheat grains under different treatments. The data presented in Table 5 reveals that the all the treatments showed the presence of different compounds but the main constituent of interest is the protein content in wheat. The data presented herein reveals the presence of peaks for amines (principal constituents of proteins) in all the samples but maximum area under the peaks was observed under the treatment $T_{5}$ which reflects that the application of recommended dose of fertilizers @ 125\% along with augmentation of vermicompost @ $2.5 \mathrm{t} /$ ha significantly provided more nitrogen to the developing wheat grains which in turn is reflected as a greater proportion of amines in the spectroscopic analysis (Fig. 1).

Effect of various treatments on cost benefit ratio of wheat cultivation is presented in Table 6. Treatment comprising of cent per cent application of RDF @ 50\% + 5 t/ha vermicompost $\left(\mathrm{T}_{7}\right)$ recorded maximum total cost of cultivation ( $₹$ 85220.62) followed by ₹ $\quad 69972.6$ obtained under treatment comprising of application of RDF@ $125 \%+$ $2.5 \mathrm{t} /$ ha vermicompost $\left(\mathrm{T}_{5}\right)$. Lowest cost of cultivation ( $₹$ 42749.18) was recorded under control $\left(\mathrm{T}_{1}\right)$. Maximum gross returns were recorded under the treatment comprising of application of RDF @ 75\% + 2.5 t/ha vermicompost wherein a return of ₹116081was realized followed by treatment $\mathrm{T}_{7}$ which recorded a gross return of $₹ 113110$ per hectare. Minimum amount of gross returns (₹66280) were recorded under control $\left(\mathrm{T}_{1}\right)$. The table further revealed that net returns were highest ( $₹$ 55636.00) under treatment where wheat plants were applied with recommended dose of fertilizers $\left(\mathrm{T}_{2}\right)$ followed by net returns of ₹ 51292.00 obtained under treatment $\mathrm{T}_{4}$ (application of RDF@ 125\%). Lowest net returns (₹ 24030.00) were obtained under control. Maximum benefit cost ratio of (2.1) was obtained under treatment comprising application of recommended dose of fertilizers $\left(\mathrm{T}_{2}\right)$ followed by benefit cost ratio of 2.0 and 1.8 obtained under treatment $\mathrm{T}_{4}$ and $\mathrm{T}_{6}$, respectively. Lowest benefit cost ratio of 1.3 was obtained under treatment comprising of application of RDF @ 50\% + 5 t/ha vermicompost $\left(\mathrm{T}_{7}\right)$. 
Table.1 Effect of integrated nutrient management on vegetative growth characters of wheat

\begin{tabular}{|c|c|c|c|c|c|}
\hline \multirow[t]{2}{*}{ Treatments } & \multicolumn{3}{|c|}{$\begin{array}{l}\text { Plant height } \\
(\mathrm{cm})\end{array}$} & \multirow[t]{2}{*}{$\begin{array}{l}\text { Number of } \\
\text { green leaves }\end{array}$} & \multirow{2}{*}{$\begin{array}{l}\text { Number of } \\
\text { tillers/meter } \\
\text { row length }\end{array}$} \\
\hline & $30 \mathrm{DAS}$ & 60 DAS & 90 DAS & & \\
\hline $\mathbf{T}_{1}$ & $23.41^{b c}$ & $35.7^{\mathrm{cd}}$ & $52.07^{\mathrm{a}}$ & $4.20^{\mathrm{a}}$ & $65.53^{\mathrm{a}}$ \\
\hline $\mathbf{T}_{2}$ & $20.83^{\mathrm{a}}$ & $33.0^{\mathrm{ab}}$ & $56.79^{b}$ & $4.53^{\mathrm{abc}}$ & $73.00^{b}$ \\
\hline $\mathbf{T}_{\mathbf{3}}$ & $22.83^{b}$ & $35.1^{c}$ & $55.20^{b}$ & $4.40^{\mathrm{ab}}$ & $70.20^{\mathrm{ab}}$ \\
\hline $\mathbf{T}_{4}$ & $22.97^{\mathrm{b}}$ & $36.2^{d}$ & $55.63^{b}$ & $4.40^{\mathrm{ab}}$ & $73.27^{b}$ \\
\hline $\mathbf{T}_{5}$ & $19.53^{\mathrm{a}}$ & $32.4^{\mathrm{a}}$ & $51.57^{\mathrm{a}}$ & $4.73^{b c}$ & $70.13^{\mathrm{ab}}$ \\
\hline $\mathbf{T}_{6}$ & $24.80^{d}$ & $39.7^{\mathrm{e}}$ & $57.60^{b}$ & $4.73^{b c}$ & $73.00^{b}$ \\
\hline $\mathbf{T}_{7}$ & $25.13^{\mathrm{de}}$ & $41.5^{\mathrm{f}}$ & $58.07^{\mathrm{b}}$ & $4.87^{\mathrm{c}}$ & $82.20^{c}$ \\
\hline S. Em. $( \pm)$ & 0.29 & 0.40 & 1.32 & 0.10 & 1.80 \\
\hline C.D. $(5 \%)$ & 0.92 & 1.27 & 2.91 & 0.32 & 5.62 \\
\hline
\end{tabular}

Treatments: $\mathrm{T}_{1}:$ Control, $\mathrm{T}_{2}: \mathrm{RDF}, \mathrm{T}_{3}: \mathrm{RDF}+2.5 \mathrm{t} / \mathrm{ha}$ Vermicompost, $\mathrm{T}_{4}: \mathrm{RDF} @ 125 \%, \mathrm{~T}_{5}: \mathrm{RDF} @ 125 \%+2.5 \mathrm{t} / \mathrm{ha}$ Vermicompost, $\mathrm{T}_{6}$ : RDF @ 75\% + 2.5 t/ha Vermicompost, $\mathrm{T}_{7}$ : RDF@ 50\% + 5 t/ha Vermicompost

Table.2 Effect of integrated nutrient management on yield characters of wheat

\begin{tabular}{|c|c|c|c|c|}
\hline Treatments & Spike length (cm) & Spikelets/spike & $\begin{array}{l}\text { Number of } \\
\text { grains/ear }\end{array}$ & $\begin{array}{l}\text { Number of ear } \\
\text { heads per } \mathrm{m}^{2}\end{array}$ \\
\hline $\mathbf{T}_{1}$ & $9.40^{\mathrm{a}}$ & $8.33^{\mathrm{a}}$ & $25.00^{\mathrm{a}}$ & $215.67^{\mathrm{a}}$ \\
\hline $\mathbf{T}_{2}$ & $10.20^{\mathrm{b}}$ & $9.33^{b}$ & $27.00^{\mathrm{abc}}$ & $294.33^{b}$ \\
\hline $\mathbf{T}_{3}$ & $10.10^{\mathrm{b}}$ & $9.33^{\mathrm{b}}$ & $26.00^{\mathrm{ab}}$ & $287.33^{\mathrm{b}}$ \\
\hline $\mathbf{T}_{4}$ & $10.20^{b}$ & $9.67^{\mathrm{bc}}$ & $26.67^{\mathrm{abc}}$ & $325.67^{\mathrm{c}}$ \\
\hline $\mathbf{T}_{5}$ & $9.93^{\mathrm{a}}$ & $8.33^{\mathrm{a}}$ & $28.33^{b c}$ & $291.67^{b}$ \\
\hline$T_{6}$ & $12.80^{c}$ & $10.67^{\mathrm{d}}$ & $28.00^{\mathrm{abc}}$ & $300.00^{b}$ \\
\hline $\mathbf{T}_{7}$ & $13.73^{d}$ & $11.67^{\mathrm{e}}$ & $29.33^{c}$ & $302.33^{b}$ \\
\hline S.E $\mathbf{m}( \pm)$ & 0.21 & 0.37 & 0.68 & 6.17 \\
\hline C.D (0.05) & 0.68 & 1.17 & 2.12 & 19.24 \\
\hline
\end{tabular}

Treatments: $\mathrm{T}_{1}$ : Control, $\mathrm{T}_{2}: \mathrm{RDF}, \mathrm{T}_{3}: \mathrm{RDF}+2.5 \mathrm{t} / \mathrm{ha}$ Vermicompost, $\mathrm{T}_{4}: \mathrm{RDF} @ 125 \%, \mathrm{~T}_{5}: \mathrm{RDF} @ 125 \%+2.5 \mathrm{t} / \mathrm{ha}$ Vermicompost, $\mathrm{T}_{6}$ : RDF @ 75\% + 2.5 t/ha Vermicompost, $\mathrm{T}_{7}: \mathrm{RDF} @ 50 \%+5 \mathrm{t} / \mathrm{ha}$ Vermicompost 
Table.3 Effect of integrated nutrient management on yield characters of wheat

\begin{tabular}{|c|c|c|c|c|c|c|}
\hline Treatment & $\begin{array}{c}\text { Test weight } \\
\text { (g) }\end{array}$ & $\begin{array}{l}\text { Seed weight } \\
\quad\left(\mathrm{g} / \mathrm{m}^{2}\right)\end{array}$ & $\begin{array}{l}\text { Grain yield } \\
\text { (q/ha) }\end{array}$ & $\begin{array}{c}\text { Straw yield } \\
\text { (q/ha) }\end{array}$ & $\begin{array}{c}\text { Biological } \\
\text { Yield } \\
\text { (q/ha) }\end{array}$ & $\begin{array}{c}\text { Harvest } \\
\text { Index } \\
\text { (HI) }\end{array}$ \\
\hline $\mathbf{T}_{1}$ & $41.90^{\mathrm{ab}}$ & $0.34^{\mathrm{a}}$ & $34.37^{\mathrm{a}}$ & $31.00^{\text {ef }}$ & $65.37^{d}$ & $52.58^{a}$ \\
\hline $\mathbf{T}_{2}$ & $42.87^{b c}$ & $0.56^{\mathrm{bc}}$ & $55.53^{b c}$ & $43.81^{c}$ & $99.34^{\mathrm{a}}$ & $55.90^{a b}$ \\
\hline $\mathbf{T}_{3}$ & $44.43^{\mathrm{cd}}$ & $0.49^{b}$ & $48.87^{b}$ & $45.73^{b}$ & $94.61^{a}$ & $51.66^{a}$ \\
\hline $\mathbf{T}_{4}$ & $40.53^{\mathrm{a}}$ & $0.55^{b c}$ & $54.80^{b c}$ & $27.29^{\mathrm{g}}$ & $82.09^{d}$ & $66.76^{b}$ \\
\hline $\mathbf{T}_{5}$ & $44.83^{\mathrm{cd}}$ & $0.55^{\mathrm{bc}}$ & $54.80^{\mathrm{bc}}$ & $37.95^{d}$ & $92.75^{b}$ & $59.08^{a b}$ \\
\hline $\mathbf{T}_{6}$ & $45.93^{d}$ & $0.63^{c}$ & $62.80^{c}$ & $33.13^{e}$ & $95.93^{b c}$ & $65.46^{b}$ \\
\hline $\mathbf{T}_{7}$ & $45.97^{d}$ & $0.60^{b c}$ & $59.50^{b c}$ & $45.8^{a b}$ & $105.44^{\mathrm{a}}$ & $56.43^{\mathrm{ab}}$ \\
\hline $\operatorname{S.Em~}( \pm)$ & 0.63 & 0.02 & 2.08 & 0.09 & 0.13 & 2.28 \\
\hline C.D. $(5 \%)$ & 1.98 & 0.06 & 6.49 & 0.29 & 0.42 & 7.11 \\
\hline
\end{tabular}

Treatments: $\mathrm{T}_{1}:$ Control, $\mathrm{T}_{2}: \mathrm{RDF}, \mathrm{T}_{3}: \mathrm{RDF}+2.5 \mathrm{t} / \mathrm{ha}$ Vermicompost, $\mathrm{T}_{4}: \mathrm{RDF} @ 125 \%, \mathrm{~T}_{5}: \mathrm{RDF} @ 125 \%+2.5 \mathrm{t} / \mathrm{ha}$ Vermicompost, $\mathrm{T}_{6}$ : RDF @ 75\% + 2.5 t/ha Vermicompost, $\mathrm{T}_{7}$ : RDF@ 50\% + 5 t/ha Vermicompost

Table.4 Effect of integrated nutrient management on nutrient availability status of the soil

\begin{tabular}{|l|c|c|c|c|c|c|}
\hline $\begin{array}{l}\text { Treatmen } \\
\mathbf{t}\end{array}$ & Soil $\mathbf{~ p H}$ & $\begin{array}{c}\mathbf{E C} \\
\left(\mathbf{d S} / \mathbf{c m}^{\mathbf{2}}\right)\end{array}$ & Available N & $\begin{array}{c}\text { Available } \\
\mathbf{P}\end{array}$ & $\begin{array}{c}\text { Available } \\
\mathbf{K}\end{array}$ & Available OC \\
\hline $\mathbf{T}_{\mathbf{1}}$ & $6.56^{\mathrm{a}}$ & $0.11^{\mathrm{a}}$ & $203.87^{\mathrm{a}}$ & $16.03^{\mathrm{a}}$ & $174.35^{\mathrm{a}}$ & $0.42^{\mathrm{a}}$ \\
\hline $\mathbf{T}_{\mathbf{2}}$ & $6.84^{\mathrm{a}}$ & $0.16^{\mathrm{b}}$ & $213.23^{\mathrm{c}}$ & $18.07^{\mathrm{b}}$ & $227.13^{\mathrm{f}}$ & $0.66^{\mathrm{c}}$ \\
\hline $\mathbf{T}_{\mathbf{3}}$ & $7.03^{\mathrm{a}}$ & $0.14^{\mathrm{ab}}$ & $210.10^{\mathrm{b}}$ & $22.03^{\mathrm{c}}$ & $214.63^{\mathrm{c}}$ & $0.75^{\mathrm{d}}$ \\
\hline $\mathbf{T}_{\mathbf{4}}$ & $6.95^{\mathrm{a}}$ & $0.17^{\mathrm{bc}}$ & $217.07^{\mathrm{d}}$ & $21.87^{\mathrm{c}}$ & $222.69^{\mathrm{e}}$ & $0.55^{\mathrm{b}}$ \\
\hline $\mathbf{T}_{\mathbf{5}}$ & $7.36^{\mathrm{a}}$ & $0.12^{\mathrm{c}}$ & $218.43^{\mathrm{d}}$ & $21.20^{\mathrm{c}}$ & $219.23^{\mathrm{d}}$ & ${ }^{\mathrm{a}} 0.69^{\mathrm{c}}$ \\
\hline $\mathbf{T}_{\mathbf{6}}$ & $7.48^{\mathrm{a}}$ & $0.13^{\mathrm{d}}$ & $222.63^{\mathrm{f}}$ & $21.63^{\mathrm{c}}$ & $228.01^{\mathrm{f}}$ & $0.79^{\mathrm{e}}$ \\
\hline $\mathbf{T}_{\mathbf{7}}$ & $7.70^{\mathrm{a}}$ & $0.13^{\mathrm{d}}$ & $219.53^{\mathrm{e}}$ & $22.17^{\mathrm{c}}$ & $208.97^{\mathrm{b}}$ & $0.76^{\mathrm{de}}$ \\
\hline $\mathbf{S . E} \mathbf{( m )}$ & 0.09 & 0.003 & 0.84 & 0.36 & 0.77 & 0.01 \\
\hline C.D & 0.30 & 0.01 & 2.62 & 1.13 & 2.42 & 0.03 \\
\hline
\end{tabular}

Treatments: $\mathrm{T}_{1}$ : Control, $\mathrm{T}_{2}: \mathrm{RDF}, \mathrm{T}_{3}: \mathrm{RDF}+2.5 \mathrm{t} / \mathrm{ha}$ Vermicompost, $\mathrm{T}_{4}: \mathrm{RDF} @ 125 \%, \mathrm{~T}_{5}: \mathrm{RDF} @ 125 \%+2.5 \mathrm{t} / \mathrm{ha}$ Vermicompost, $\mathrm{T}_{6}$ : RDF @ 75\% + 2.5 t/ha Vermicompost, $\mathrm{T}_{7}$ : RDF@ 50\% + 5 t/ha Vermicompost 
Table.5 FTIR spectroscopic analysis of wheat under different integrated nutrient management treatments

\begin{tabular}{|c|c|c|c|c|c|c|c|c|c|c|c|c|c|c|c|}
\hline & $T$ & & $\mathbf{T}$ & & $\mathbf{T}$ & & $\mathbf{T}$ & & $\mathbf{T}$ & & $\mathbf{T}$ & & $T$ & & Compound \\
\hline & Peak & Area & Peak & Area & Peak & Area & Peak & Area & Peak & Area & Peak & Area & Peak & Area & \\
\hline 1 & 524.66 & 9.2 & 526.58 & 16.44 & 528.51 & 12.68 & 526.58 & 22.50 & 526.58 & 23.44 & 526.58 & 15.70 & 528.51 & 9.02 & $\mathrm{C}-\mathrm{Br}$ stretch \\
\hline 2 & 572.88 & 14.5 & 574.81 & 16.68 & 576.74 & 13.45 & 574.91 & 23.85 & 574.81 & 24.72 & 574.81 & 14.65 & 576.74 & 9.58 & C-Br stretch \\
\hline 3 & 675.11 & 15.03 & 669.32 & 13.80 & 689.32 & 7.78 & 709.93 & 18.49 & 709.83 & 20.23 & 673.18 & 11.38 & 671.25 & 8.74 & $\mathrm{C}-\mathrm{H}$ bending (Alkynes) \\
\hline 4 & 761.91 & 18.86 & 763.84 & 20.43 & 761.91 & 16.56 & 763.84 & 27.49 & 763.84 & 28.50 & 761.91 & 20.14 & 761.91 & 11.19 & $\begin{array}{l}\text { Out-of-plane } \mathrm{C}-\mathrm{H} \\
\text { bending }\end{array}$ \\
\hline 5 & 858.35 & 11.88 & 858.35 & 13.39 & 856.42 & 10.65 & 858.36 & 17.64 & 858.35 & 19.54 & 856.42 & 14.91 & 856.42 & 7.20 & $\beta$-D-sucrose \\
\hline 6 & 929.72 & 14.50 & 929.72 & 15.91 & 929.72 & 12.66 & 929.72 & 21.98 & 929.72 & 22.98 & 929.72 & 15.61 & 929.72 & 9.08 & $\beta$-D-cellulose \\
\hline 7 & 1016.52 & 43.30 & 1020.38 & 49.44 & 1022.31 & 36.33 & 1020.38 & 73.76 & 1020.38 & 76.30 & 1022.31 & 42.21 & 1022.31 & 34.52 & Cellulose and phenols \\
\hline 8 & 1082.1 & 22.09 & 1082.1 & 25.50 & 1082.1 & 19.00 & 1082.1 & 37.59 & 1082.1 & 39.06 & 1084.03 & 22.17 & 1082.1 & 17.59 & Cellulose and phenols \\
\hline 9 & 1155.4 & 26.48 & 1157.33 & 29.76 & 1155.4 & 22.30 & 1155.4 & 34.39 & 1155.4 & 44.55 & 1156.4 & 27.51 & 1155.4 & 19.46 & Cellulose and phenols \\
\hline 10 & 1242.2 & 13.30 & 1242.2 & 15.77 & - & - & 1242.2 & 23.14 & 1242.2 & 23.00 & - & - & 1242.2 & 10.38 & $\begin{array}{l}\text { Hemicelluloses and } \\
\text { phenols }\end{array}$ \\
\hline 11 & 1373.36 & 18.34 & 1379.15 & 13.16 & - & - & 1375.29 & 21.00 & 1377.22 & 21.95 & 1379.15 & 8.94 & 1381.08 & 21.88 & $\begin{array}{l}\text { Aromatic nitro } \\
\text { compound } \mathrm{NO}_{2} \\
\text { symmetric stretching }\end{array}$ \\
\hline 12 & 1417.73 & 11.17 & 1415.8 & 15.78 & 1413.87 & 13.29 & 1415.8 & 20.18 & 1415.8 & 20.31 & - & - & - & - & Amine \\
\hline 13 & 1456.3 & 12.77 & - & - & - & - & - & - & 1454.38 & 23.28 & 1452.45 & 14.57 & - & - & Amine \\
\hline 14 & 1548.89 & 7.14 & 1546.96 & 23.54 & 1554.68 & 18.59 & 1541.18 & 30.11 & 1546.96 & 31.69 & 1554.68 & 7.26 & 1545.03 & 13.88 & Amine \\
\hline 15 & 1649.19 & 35.24 & 1651.12 & 63.90 & 1641.48 & 34.83 & 1651.12 & 94.99 & 1651.12 & 103.53 & 1649.19 & 23.07 & 1651.12 & 41.57 & Amine \\
\hline 16 & - & - & - & - & 2362.98 & 10.84 & - & & 2360.95 & 13.75 & 2362.88 & 14.56 & 2362.88 & 8.36 & Saturated carbons \\
\hline 17 & 2926.11 & 110.84 & 2928.04 & 144.69 & 2926.11 & 32.16 & 2928.04 & 182.59 & 2926.11 & 213.35 & 2926.11 & 40.20 & 2928.04 & 85.84 & Saturated carbons \\
\hline 18 & 3417.98 & 31.94 & 3419.9 & 288.85 & 3423.76 & 217.14 & 3398.69 & 5.16 & 3417.98 & 466.91 & 3421.83 & 147.29 & 3414.12 & 201.34 & O-H stretching (water) \\
\hline 19 & 3743.96 & 10.05 & - & - & - & - & - & - & - & - & - & - & - & - & Amide N-H Stretch \\
\hline
\end{tabular}


Table.6 Effect of different integrated nutrient management on economics of wheat cultivation

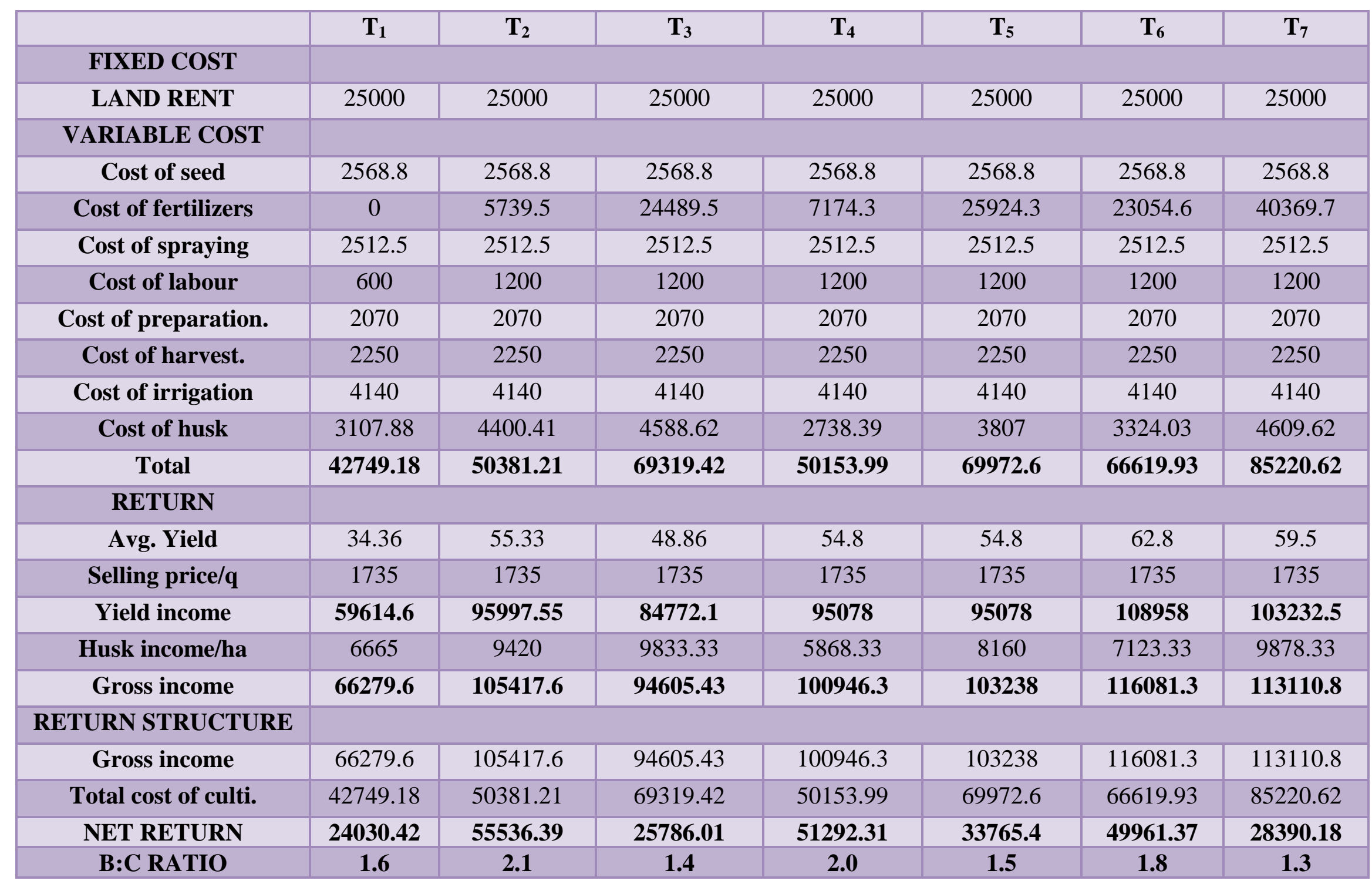


Fig.1 FTIR characterization of wheat under different inorganic and organic fertilizer treatments
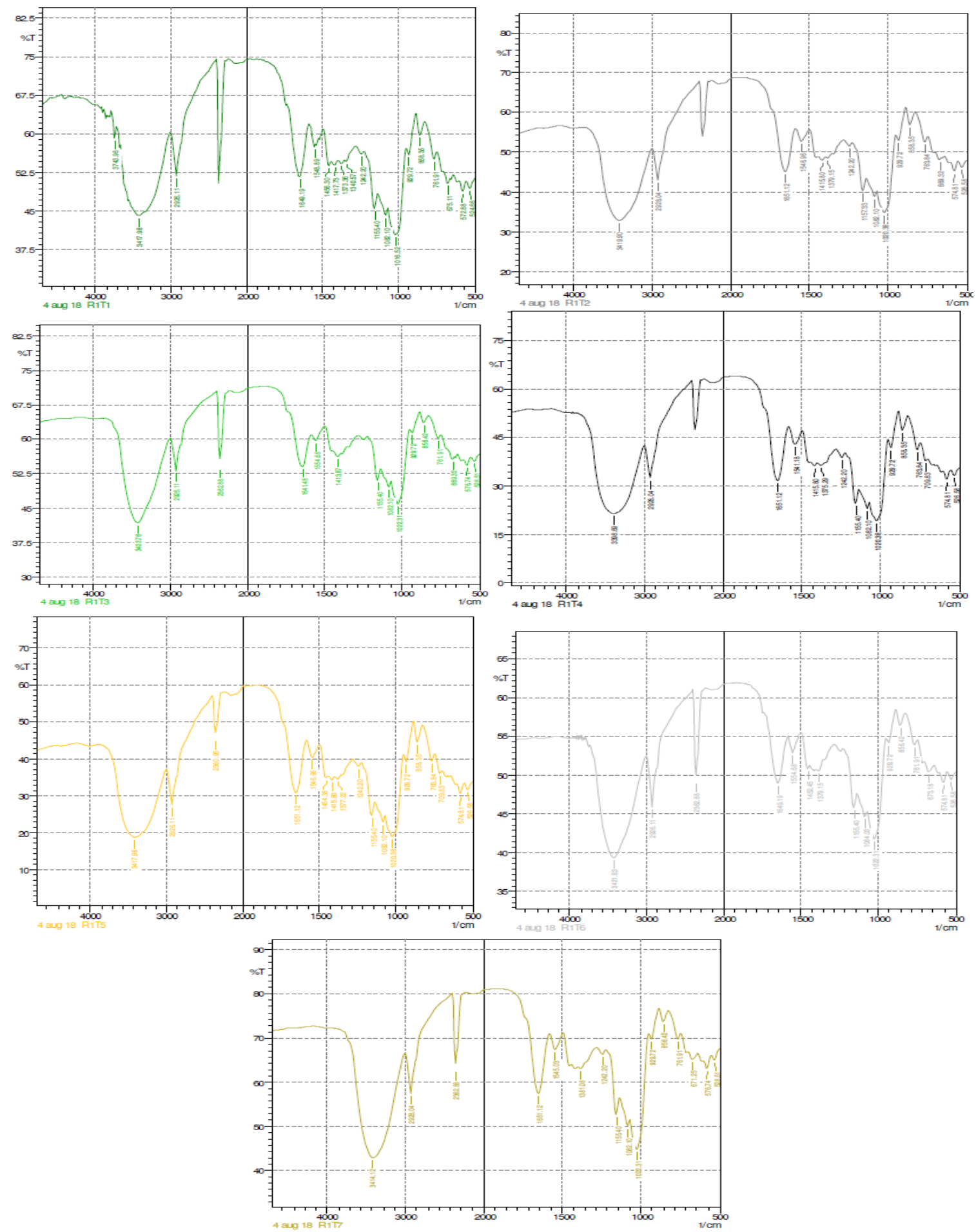

Wheat crop under the experiment performed better for vegetative parameters with the application $f$ both inorganic and organic sources of fertilizers. Better performance of wheat plant under the effect of combined application of inorganic and organic fertilizers may be due to the fact that organic manures ensured longevity in supply of nutrients 
which resulted in stimulation of cell division and elongation of internodes (Zaki et al., 2012). Similar findings have been reported by Cherr et al., (2006). Many researchers reported that combined application of manures and fertilizers increased the plant height and tillers hill ${ }^{-1}$ (Khan et al., 2007), spike length, (Singh et al., 2011) and filled grains spike $^{-1}$ (Satyannarayana et al., 2002). Increase in grain yield is a function of nutrient availability to the plants. Under the current experiment, organic matter like vermicompost has supplied nutrients to the plants providing a favourable soil environment and increased water holding capacity of the soil. Increased straw yield per ha under treatment $\mathrm{T}_{7}$ may be attributed to the fact that maximum vegetative growth was also recorded under the same treatment as reported by Brar et al., (2015) in pearl millet-wheat cropping system.

It was observed that treatments involving the application of inorganic fertilizers were high on EC values due to availability of nutrient ions as reported by (Krishna et al., 2004). Elevated nutrient status of the soil under the application of inorganic and organic sources of fertilizers can be attributed to the fact that organic manures are the sink of nutrients that is available in soil for a longer duration as reported by Singh et al., (2008). Singh et al., (2013) also reported similar findings wherein availability of phosphorus in the soil increased with the combined application of fertilizers and manures as compared to cent per cent application of NPK due to solubalization of naïve $\mathrm{P}$ in the soil under the effect of released organic acids from organic manures.

Highest amount of protein content in the treatment involving RDF@125 + 2.5 t/ha Vermicompost is due to the availability of nitrogen in a bounty which was reflected in the grains. The economics of cultivation was highest under RDF dose primarily due to the fact that incorporation of organic manures increased the cost of production.

\section{Acknowledgements}

Research support provided by the Division of Agronomy, Lovely Professional University in particular and School of Agriculture, Lovely Professional University in general for conduct of this research work are duly acknowledged.

\section{References}

Anonymous. 2013. Package of practices for crops of Punjab: Rabi. Punjab Agricultural University. pp: 1-17

Anonymous. 2016. Annual Report 2016-17. Department of Agriculture, cooperation and farmers welfare. Ministry of Agriculture and Farmers welfare, Govt. of India. pp. 3.

Brar, B. S., Singh, J., Singh, G. and Kaur, G. 2015 Effects of long term application of in organic and organic fertilizers on the soil organic carbon and physical properties in maize- wheat rotation. Agronomy. 5: 220-238.

Cherr, C. M., Scholberg, J. M. S. and Sorley, R. M. 2006. Green manure approach to crop production. Agronomy Journal. 98: 302-319.

Khan, M. U., Qasim, M., Khan, I. U. 2007. Effect of integrated nutrient management on crop yields in ricewheat cropping system. Sarhad Journal of Agriculture. 23 (4): 1019-1025.

Marin, A. M. P., Menezes, R. S. C. and Salcedo, I. H. 2007. Productivity of maize intercropped or not with Gliricidia amended with two organic fertilizers. Pesquisa Agropecuária Brasileira. 42, 615-625.

Mervin, M. D. and Peech, M. 1951. Exchangeability of soil $\mathrm{K}$ in sand, silt and clay fraction as influenced by the nature of complementary exchangeable 
cations. Proceedings of American Soil Science Society. 15:125-128.

Nkonya, E., Kaizzi, C. and Pender, J. 2005. Determination of nutrient balances in a maize farming system in eastern Uganda. Agricultural Systems. 85, 155182.

Olsen, S. R., Cole, C. V., Watanable, F. S. and Dean, L. A. 1954. Estimation of available phosphorus in soil by extraction with sodium bicarbonate USDA Cir pp: 939.

Piper, C. S. 1966. Soil and Plant Analysis. Hans Publishers, Bombay. 40-51pp.

Satyanarayana, V., Prasad P. V. V., Murthy, V. R. K., Bodty, K. J. 2002. Influence of integrated use of inorganic fertilizers on yield components of irrigated low land rice. Journal of Plant Nutrition. 87(1-3): 90-93.

Shree, S., Singh, V. K. and Kumar, R. 2014. Effect of integrated nutrient management on yield and quality of cauliflower (Brassica oleracea var. Botrytis L.). The Bioscan. 9(3): 1053 1058
Singh, A. B., Saha, J. K. and Ghosh, P. K. 2008. Effect of nutrient management practices on soyabean-chickpea cropping systems for improving seed yield, quality and soil biological health under rainfed condition. Indian Journal of Agricultural Science. 78(6): 485-489.

Singh, C. M., Sharma, P. K., Kishor, P., Mishra, P. K., Singh, A. P., Verma, R. and Raha, P. 2011. Impact of integrated nutrient management on growth, yield and nutrient uptake by wheat (Triticum aestivum L.) Asian Journal of Agricultural Research. 5(1): 76-82.

Subbiah, B. V. and Asija, G. L. 1956. A rapid procedure for the estimation of available nitrogen in soil. Current Science. 25: 259-60.

Zaki, N. M., Gomaa, M. A., Radwan, F. I., Hassanein, M. S. and Wali, A. M. 2012. Effect of mineral, organic and biofertilizers on yield, yield components and chemical composition of some wheat cultivars. Journal of Applied Sciences and Research. 8: 174-191.

\section{How to cite this article:}

Rashpinder Singh, Manish Bakshi, Kuljeet Singh, Sarwan Singh and Terwinder Singh Brar. 2019. Evaluation of Wheat (Triticum aestivum L.) under Inorganic and Organic Fertilization Using FTIR Spectroscopy. Int.J.Curr.Microbiol.App.Sci. 8(07): 302-311. doi: https://doi.org/10.20546/ijcmas.2019.807.037 